\title{
IMPLEMENTASI ALGORITMA GENETIKA BERBASIS WEB PADA SISTEM PENJADWALAN MENGAJAR DI SMK DWIJENDRA DENPASAR
}

\author{
Ni Luh Wiwik Sri Rahayu Ginantra ${ }^{1)}$ Ida Bagus Gede Anandita ${ }^{2)}$ \\ Program Studi Teknologi Informasi ${ }^{1{ }^{12}}$ \\ Jurusan Manajemen Teknologi Informasi, STMIK STIKOM Indonesia, Denpasar, Bali ${ }^{1{ }^{12)}}$ \\ wiwik@stiki-indonesia.ac.id ${ }^{(1)}$ idabagus.anandita@stiki-indonesia.ac.id ${ }^{2)}$
}

\begin{abstract}
Intelligence from a computer that can mimic the human work system is commonly referred to as artificial intelligence which can solve problems (problem solving) that are complicated and sometimes humans themselves cannot solve them, as in the process of scheduling subjects. The preparation of scheduling school subjects is prepared by considering several components including; Teachers, time, majors, levels, and subjects themselves. Based on these problems the researchers conducted a study of scheduling school subjects with the method of Genetic Algorithm and took a case study at one of the private vocational high schools in Denpasar, namely SMK Dwijendra Denpasar. Based on the results of the design and discussion that have been conducted, scheduling teaching with Genetic Algorithms with case studies at Dwijendra Vocational School can be done by using subject data and teachers from the Vocational School and producing teaching schedules for teachers at the school so that there is no schedule clash. The results of testing carried out in this study are by testing measurements of population size and size of generations. The test was carried out by using a population size and generation of 150 with a crossover rate (cr) of 50\%. The test results show that in a small population and generation produce a variety of fitness values. Good fitness values are generated in populations and generations above 50.
\end{abstract}

Keywords: Genetic Algorithms, Scheduling, Lesson Type.

\begin{abstract}
ABSTRAK
Kecerdasan dari komputer yang dapat meniru system kerja manusia biasa disebut dengan istilah kecerdasan buatan (artificial intelegence) yang dapat memecahkan masalah (problem solving) yang rumit dan kadang manusia sendiri tidak dapat menyelesaikannya, seperti dalam proses penjadwalan mata pelajaran. Penyusunan penjadwalan mata pelajaran sekolah disusun dengan mempertimbangkan beberapa komponen diantaranya ; Guru, waktu, jurusan, jenjang, dan mata pelajaran itu sendiri. Berdasarkan permasalahan tersebut peneliti melakukan penelitian tentang penjadwalan mata pelajaran sekolah dengan metode Algoritma Genetika dan mengambil studi kasus pada salah satu sekolah menengah kejuruan (SMK) swasta di Denpasar yaitu SMK Dwijendra Denpasar. Berdasarkan hasil perancangan dan pembahasan yang telah dilakukan, penjadwalan mengajar dengan algoritma Genetika dengan studi kasus di SMK Dwijendra dapat dilakukan dengan menggunakan data mata pelajaran dan guru dari SMK tersebut dan menghasilkan jadwal mengajar bagi guru di sekolah tersebut sehingga tidak terjadinya bentrokan jadwal. Hasil pengujian yang dilakukan pada penelitian ini yaitu dengan pengujian pengukuran ukuran populasi dan ukuran ukuran generasi. Pada pengujian tersebut dilakukan dengan menggunakan ukurun populasi dan generasi sebanyak 150 dengan crossover rate (cr) 50\%. Hasil pengujian menunjukan bahwa pada populasi dan generasi sedikit menghasilkan nilai fitness yang beragam. Nilai fitness yang baik dihasilkan pada populasi dan generasi diatas 50 .
\end{abstract}

Kata Kunci : Algoritma Genetika, Penjadwalan, Mata Pelajaran.

\section{PENDAHULUAN}

Perkembangan teknologi informasi yang semakin cepat saat ini dan berkembang diharapkan dapat memberikan manfaat dalam segala aspek kehidupan termasuk dalam membantu kegiatan manusia. Kecerdasan dari komputer yang dapat meniru system kerja manusia biasa disebut dengan istilah kecerdasan buatan (artificial intelegence) yang dapat memecahkan masalah (problem solving) yang rumit yang kadang manusia sendiri tidak dapat menyelesaikannya, seperti dalam proses 
penjadwalan mata pelajaran di sekolah menengah kejuruan. Penyusunan penjadwalan mata pelajaran sekolah disusun dengan mempertimbangkan beberapa komponen diantaranya ; Guru, waktu, jurusan, jenjang, dan mata pelajaran itu sendiri. Penyusunan jadwal yang baik, harus memperhatikan korelasi antar komponen agar tidak terjadinya "tabrakan" jadwal. Keterbatasan guru bidang studi dengan program keahlian yang berbeda menjadi salah satu pertimbangan dalam menyusun jadwal pelajaran . Selain menghindari terjadinya "tabrakan" jadwal ada parameter lain yang juga menjadi permasalahan diantaranya jumlah jam mengajar guru dalam satu hari, tidak boleh adanya pengulangan mata pelajaran yang sama dalam satu hari. Dengan permasalahan ini, sumber daya manusia yang bertugas membuat jadwal yang merupakan tugas dari wakil kepala sekolah bagian kurikulum tentunya akan mendapat kesulitan membuat jadwal tentunya akan mendapat kesulitan. Berdasarkan permasalahan tersebut peneliti melakukan penelitian tentang penjadwalan mata pelajaran sekolah dengan metode Algoritma Genetika dan mengambil studi kasus pada pada salah satu sekolah menengah kejuruan (SMK) swasta di Denpasar yaitu SMK Dwijendra Denpasar. Algoritma Genetika merupakan salah satu jalan untuk memecahkan masalah penjadwalan dengan solusi yang cukup baik. Algoritma Genetika menggunakan teknik yang terinspirasi oleh biologi evolusioner seperti warisan, mutasi, seleksi alam dan rekombinasi (crossover). Harapan arah penelitian ini adalah dapat membantu wakil kepala sekolah bagian Kurikulum di SMK Dwijendra Denpasar dalam hal penyusunan jadwal mata pelajaran.

\section{TINJAUAN PUSTAKA}

\section{Algoritma Genetika}

Algoritma Genetika sebagai cabang dari Algoritma Evolusi yang merupakan metode adaptive yang biasa digunakan untuk memecahkan pencarian nilai dalam sebuah masalah optimasi. Menurut Suyanto (2005) Algoritma Genetika adalah algoritma pencarian yang didasarkan pada mekanisme seleksi ilmiah dan genetika alamiah. Konsep yang ada dalam kaidah genetika diterapkan dalam algoritma komputasi yang dapat menyelesaikan masalah dengan constrain tinggi. Mengambil konsep genetika biologi, beberapa istilah yang ada dalam Algoritma Genetika juga menggunakan konsep yang sama seperti :

a. Populasi, merupakan sekumpulan individu yang akan diproses bersama dalam satu siklus proses evolusi.

b. Genotype (Gen), sebuah nilai yang menyatakan satuan dasar yang membentuk suatu arti tertentu dalam satu kesatuan gen yang dinamakan kromosom. Dalam algoritma Genetika gen biasanya berupa nilai biner, float, integer maupun karakter.

c. Kromosom, gabungan gen-gen yang membentuk nilai tertentu.

d. Individu, menyatakan satu nilai atau keadaan yang menyatakan salah satu solusi yang mungkin dari permasalahan yang diangkat.

e. Generasi adalah jumlah tingkatan peranakan sebuah kelompok populasi yang akan dikembangbiakkan menjadi populasi mutan, mengalami crossover dan mutasi beberapa kali sehingga menghasilkan generasi terbaik atau satu iterasi dalam algoritma genetika.

\section{Crossover}

Crossover atau yang biasa dikenal dengan istilah kawin silang merupakan prosedur memasang dua buah individu dengan kemudian dipisahkan gen dan pasangannya dengan gen pasangannya. Sebuah individu akan mendapatkan solusi yang bagus jika dilakukan proses crossover dua buah individu (Suyanto,2005).

Pada proses Crossover ini merupakan proses penambahan keanekaragaman string dalam suatu populasi. Operator pindah silang memiliki peran yang penting dalam algoritma Genetika karena di dalamnya terdapat proses persilangan gen dengan gen yang lainnya yang akan menghasilkan individu baru.

\section{Seleksi Roulette}

Seleksi Roulette adalah salah satu metode seleksi individu yang tetap melibatkan keanekaragaman populasi. Metode ini meniru permainan roulette wheel dimana setiap individu menempati posisinya pada lingkaran Roulette sesuai dengan nilai fitnessnya (Suyatno, 2005)

\section{Mutasi}

Mutasi merupakan proses mengubah nilai dari satu atau beberapa gen dalam suatu kromosom. 
Mutasi menciptakan individu baru dengan melakukan perubahan nilai satu atau lebih gen dalam individu yang sama. Mutasi berfungsi untuk menggantikan gen yang hilang dari populasi selama proses seleksi serta menyediakan gen yang tidak ada dalam populasi. Secara umum mutase dapat dilakukan dengan membangkitkan nilai secara random yang kurang dari probabilitas mutase (mutasi rate) kemudian gen yang ada diubah menjadi kebalikannya.

\section{Website}

Menurut Kadir (2006,2-4), World Wide Web (WWW) atau biasa disebut dengan Web merupakan salah satu sumberdaya internet yang berkembang pesat. Saat ini, informasi Web didistribusikan melalui pendekatan hyperlink, yang memungkinkan suatu teks, gambar, ataupun objek yang lain menjadi acuan untuk membuka halaman-halaman Web yang lain. Pada awalnya aplikasi web dibangun hanya dengan menggunakan bahasa yang disebut HTML (HyperText Markup Languange) dan protokol yang digunakan dinamakan HTTP (HyperText Transfer Protocol). Pada peerkembangan berikutnya, sejumlah script dan objek yang dikembangkan untuk memperluas kemampuan HTML. Pada saat ini, banyak script seperti itu; antara lain PHP dan ASP, sedangkan contoh yang berupa objek antara lain adalah applet (Java). Aplikasi web sendiri dapat dibagi menjadi web statis dan web dinamis. Web statis dibentuk dengan mengguankan HTML saja. Kekurangan aplikasi ini terletak pada keharusan untuk memelihara program secara terus-menerus untuk mengikuti setiap perubahan yang terjadi. Kelamahan ini dapat diatasi dengan model aplikasi web dinamis.

Dengan memperluas kemampuan HTML, yakni dengan menggunakan perangkat lunak tambahan. Perubahan informasi dalam halaman-halaman web dapat ditangani melalui perubahan data, bukan melalui perubahan program. Sebagai implementasinya, aplikasi web dapat dikoneksikan ke basis data. Dengan demikian perubahan informasi dapat dilakukan oleh operator atau yang bertanggung jawab terhadap kemutakhiran data, dan tidak menjadi tanggung jawab pemrogram atau webmaster. Konsep yang mendasari aplikasi web sebenarnya sederhana. Operasi yang melatarbelakanginya melibatkan pertukaran informasi antara komputer yang meminta informasi, yang disebut klien, dan komputer yang memasok informasi disebut server. Lebih detailnya, server yang melayani permintaan dari klien sesungguhnya berupa suatu perangkat lunak yang dinamakan web server. Secara internal, web server inilah yang berkomunikasi dengan perangkat lunak lain yang disebut middleware dan middleware inilah yang berhubungan dengan basis data (database). Model seperti inilah yang mendukung web dinamis.

\section{METODE PENELITIAN}

\section{Tempat dan Waktu Penelitian}

Penelitian ini dilaksanakan dengan mengambil studi kasus pada salah satu Sekolah Menengah Kejuruan (SMK) swasta yaitu SMK Dwijendra beralamat di Jalan Suradipa, Peguyangan, Denpasar yang menyediakan objek penelitian berupa mata pelajaran, nama guru, kelas dan waktu pelajaran.

\section{Tahapan Penelitian}

Penelitian dilakukan dengan cara melakukan prosedur kerja yang diuraikan pada Gambar 4.1. Tahapan pertama dari penelitian ini adalah melakukan persiapan awal yang meliputi bentuk dari penelitian. Langkah kedua adalah melakukan obeservasi dan melakukan kajian tentang algoritma genetika pada proses penjadwalan (analisa). Tahap selanjutnya adalah tahap perancangan system (design) dan implementasi (Coding). 


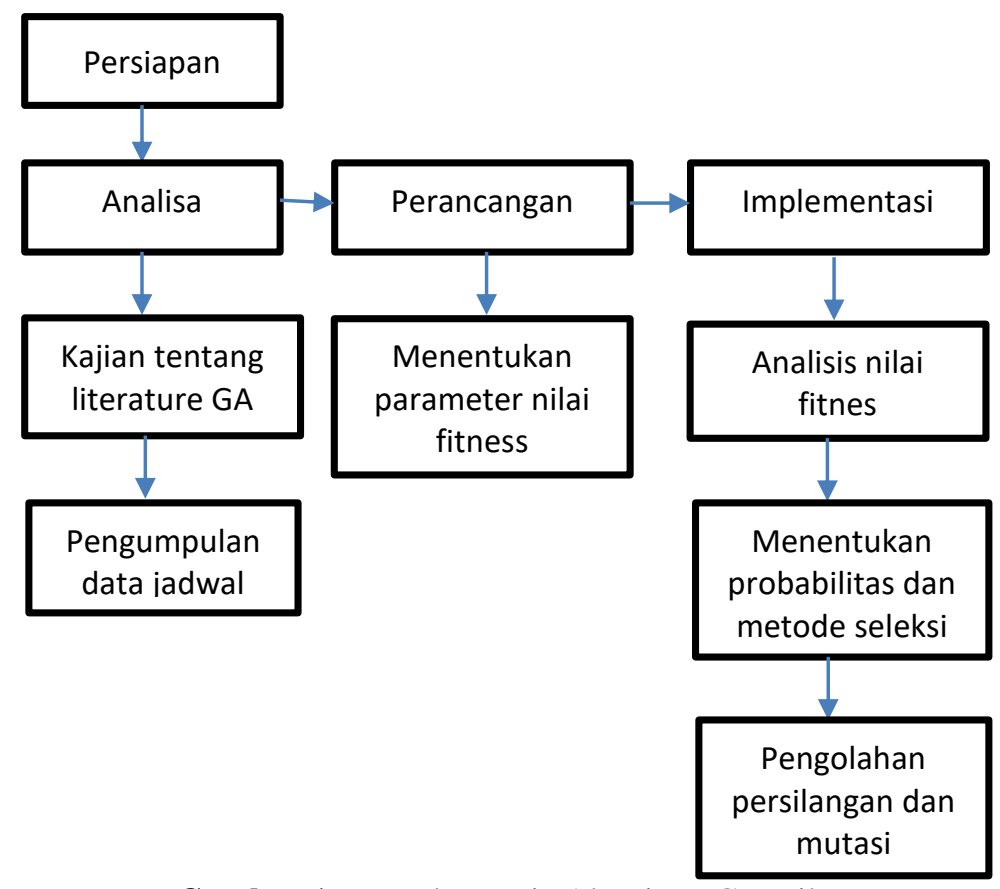

Gambar 1. Prosedur Kerja Algoritma Genetika

\section{Teknik Pengumpulan Data}

Pengumpulan data dilakukan dengan studi literatur dan observasi pada objek penelitian.

1. Studi Literatur

Melakukan studi literatur untuk mendapatkan acuan/referensi berupa buku dan jurnal-jurnal terkait judul penelitian tentang algoritma genetika pada penjadwalan mata pelajaran pada jenjang SMK.

2. Observasi

Kegiatan pengumpulan data dilakukan dengan mengamati proses yang berlangsung berkaitan dengan penyusunan penjadwalan di SMK Dwijendra yang sedang berjalan.
Teknik Pengaplikasian Algoritma Genetika

Istilah-istilah dan bagian algoritma genetika yang akan dipergunakan dalam penjadwalan akan dijelaskan dalam tabel 1 . Dalam metode pembuatan jadwal pelajaran, algoritma genetika memiliki beberapa tahapan yaitu:

1. Pembangkitan individu.

2. Evaluasi fungsi objektif dan nilai fitness

3. Penentuan nilai probabilitas

4. Seleksi dengan Roulette Wheel

5. Crossover/perkawinan silang

6. Mutasi

7. Pembangkitan individu baru

Tabel 1. Istilah dalam Algoritma Genetika

\begin{tabular}{|l|l|}
\hline \multicolumn{1}{|c|}{ Nama Istilah } & \multicolumn{1}{c|}{ Keterangan } \\
\hline Populasi & $\begin{array}{l}\text { Jumlah jadwal acak yang dibangkitkan dengan jumlah tertentu. Contoh } \\
\text { jadwal 1 dan jadwal 2 dikatakan sebagai satu kesatuan populasi. }\end{array}$ \\
\hline Kromosom = Jadwal & $\begin{array}{l}\text { Satu kesatuan jadwal dinamakan individu yang memiliki identitas } \\
\text { kromosom yang berbeda-beda. Panjang kromosom dipengaruhi oleh } \\
\text { panjang gen yaitu banyaknya pertemuan dalam satu jadwal. }\end{array}$ \\
\hline Gen = Pertemuan & Tiap pertemuan disebut gen untuk kromosom jadwal \\
\hline Crossover & $\begin{array}{l}\text { Proses perkawinan silang, sepasang individu di silangkan dengan individu } \\
\text { lain melalui proses pemotongan matrik }\end{array}$ \\
\hline Iterasi & Bilangan yang menunjukan perulangan tingkat generasi. \\
\hline Mutasi & $\begin{array}{l}\text { Pergantian struktur gen di dalam individu yang dibangkitkan secara } \\
\text { random. }\end{array}$ \\
\hline
\end{tabular}




\section{Analisa Aplikasi Algoritma Genetika}

1. Pembangkitan Generasi Awal

Sebelum pembangkitan generasi awal, ada beberapa pengaturan yang harus dibuat ketika merancang aplikasi antara lain:

a. Jumlah Kromosom

Kromosom adalah kumpulan gen-gen (kombinasi antara matapelajara, guru dan waktu). Diawal ditentukan jumlah kromosom yang dibangkitkan. Semakin banyak pilihan solusi (jadwal) yang dihasilkan, yang nantinya akan dipilih satu yang terbaik. Kromosom akan disimpan ke dalam sebuah array dengan format seperti berikut :

Kromosom

$1=\{[0,3,5],[1,5,13], \ldots[30,4,0]\}$, yang artinya kromosom 1 memiliki 30 gen (30 pembelajaran). Setiap gen merupakan kombinasi dari matapelajaran, guru dan waktu. Semakin banyak kromosom yang dibangkitkan maka akan semakin berat proses generate jadwal.

b. Maksimal Generasi

Proses algoritma genetika akan berhenti jika sudah mencapai nilai fitness 1 (tidak ada bentrokan). Namun jika masih terjadi bentrokan maka akan diulang proses generasi berikutnya.

2. Evaluasi Fitness

Penentuan nilai fitness merupakan salah satu langkah dalam penjadwalan dengan algoritma Genetika. Fitness terbaik adalah fitness yang bernilai paling besar (1).

Dalam penjadwalan dengan algoritma Genetika fitness dapat ditentukan sebagai berikut :

a. Clash Class (CC), jumlah jadwal kelas yang sama diwaktu yang sama

b. Clash Guru (CG), jumlah jadwal guru yang sama mengajar diwaktu yang sama.

Sehingga perhitungan nilai fitness adalah $\mathrm{F}=1 /(1+\mathrm{CC}+\mathrm{CD})$

3. Roulette Wheel Adapun cara kerja metode roulette ini adalah sebagai berikut : a. Hitung nilai fitness dari masingmasing individu, misal terdapat 4 kromosom yang dibangkitkan dengan masing-masing fitness :

$\begin{array}{ll}\text { Kromosom 1 } & : 0.8 \\ \text { Kromosom 2 } & : 0.3 \\ \text { Kromosom 3 } & : 0.5 \\ \text { Kromosom 4 } & : 0.4\end{array}$

b. Hitung total fitness dari semua individu

Total fitness : $0.8+0.3+0.5+0.4=2$

c. Hitung probabilitas masing-masing individu

$$
\begin{aligned}
& \mathrm{P} 1=0.8 / 2=0.4 \\
& \mathrm{P} 2=0.3 / 2=0.15 \\
& \mathrm{P} 3=0.5 / 2=0.25 \\
& \mathrm{P} 4=0.4 / 2=0.2
\end{aligned}
$$

d. Dari probabilitas kemudian hitung jatah masing-masing individu pada angka 1 sampai 100. Penentuan jatah dilakukan dengan mencari akumulatif dari probabilitas

$$
\begin{aligned}
& \text { PK1 }=0+0.4=0.4 \\
& \text { PK2 }=0.4+0.15=0.55 \\
& \text { PK3 }=0.55+0.25=0.80 \\
& \text { PK4 }=0.80+0.2=1
\end{aligned}
$$

e. Bangkitkan bilangan acak antara 0-1 sejumlah kromosom

Dari bilangan acak yang dihasilkan kita menentukan individu mana yang terpilih dalam tahap seleksi.

4. Crossover

Pindah silang (crossover) merupakan pertukaran gen antara dua buah kromosom. Kromosom yang menjadi induk dipilih secara acak sebanyak crossover rate (CR) yang sudah ditentukan dari awal. Sebagai contoh kita memiliki sampel ada 10 kromosom dengan CR 70\% maka induk yang digunakan adalah 7. Dari 7 induk ini akan dipasangkan dua dua yang menghasilkan 1 individu baru. Pasangan induk yang terjadi adalah 7 pasang yaitu induk 1, induk 2 dan seterusnya sampai dengan induk ke-7 dan setiap induk akan berpasangan 2 kali.

5. Mutasi

Mutasi adalah pergantian gen. Gen yang dimutasi hanya diganti ruang, dan waktunya saja. Untuk pelajaran tetap. Untuk jumlah gen diganti tergantung Mutation Rate (MR). Misal terdapat 5 
kromosom dengan 10 gen masing-masing, dengan MR 50\% maka didapatkan jumlah mutasi sebanyak :

Total gen : jumlah kromosom * jumlah gen per kromosom

Total gen : $5^{*} 10=50$ gen

Jumlah Mutasi $=50 \% * 50=25$ gen .

Cara mutasi adalah membangkitkan bilangan acak antara 1 sampai total gen 50 yaitu 25 kali. Apabila bilangan acak pertama adalah 12 maka akan diambil kromosom gen kedua. Hal ini disebabkan oleh kromosom pertama hanya tersedia 10 dan 2 gen lainnya akan diambil pada kromosom kedua. Sehingga ruang dan waktu gen kedua dikromosom kedua akan diganti dengan mengambil data ruang dan waktu secara acak.

\section{Perancangan Database}

Perancangan database untuk penjadwalan pelajaran dengan algoritma Genetika dapat dijabarkan dalam conseptual data model (CDM) dan Pysical Data Model (PDM). Conseptual data model (CDM) digunakan untuk menggambarkan secara detail struktur basis data dalam bentuk logic, sedangkan Pysical Data Model (PDM) merupakan penggambarang perancangan yang memperlihatkan struktur penyimpanan data yang benar pada basis data yang digunakan sesungguhnya. Pada Penjadwalan Pelajaran dengan algoritma Genetika ini penggambaran CDM terdiri dari sepuluh tabel yaitu; tabel admin, tabel waktu, tabel jurusan, tabel kelas,tabel jam, tabel jadwal, tabel maple, tabel pelajaran dan tabel guru. Conseptual data model (CDM) penjadwalan pelajaran dengan algoritma Genetik digambarkan pada gambar 2 dan Pysical Data Model (PDM) pada gambar 3

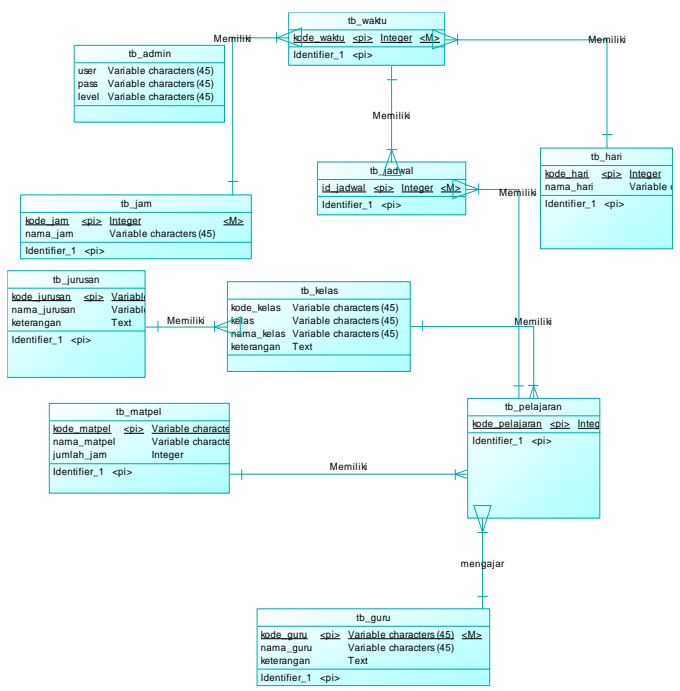

Gambar 2. Conceptual Data Model (CDM) Penjadwalan Pelajaran dengan Algoritma Genetika

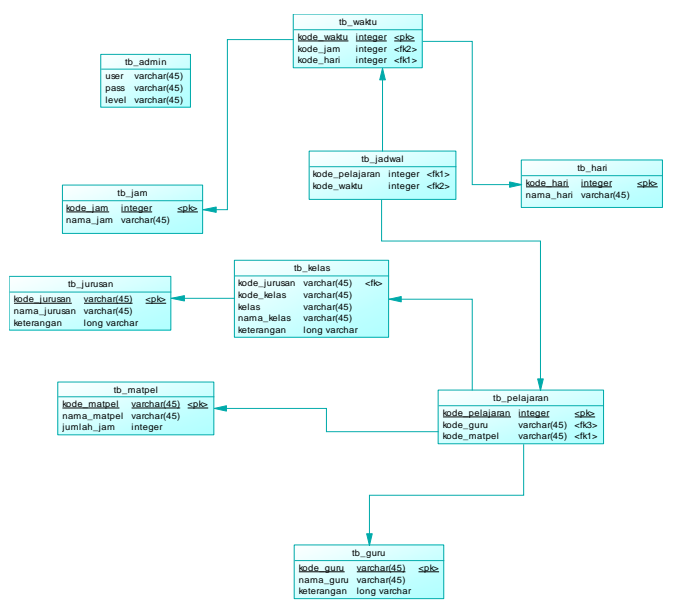

Gambar 3. Pysical Data Model (PDM)

Penjadwalan Pelajaran dengan Algoritma Genetika

\section{HASIL DAN PEMBAHASAN}

Antarmuka Sistem

1. Halaman Waktu

Halaman waktu adalah halaman yang digunakan untuk menambahkan, menghapus dan mengubah penggabungan antara jam danmm waktu dimana data waktu berperan menentukan waktu setiap hari dan setiap jam pelajaran. Tampilan halaman waktu dapat dilihat pada gambar 6.3 . 


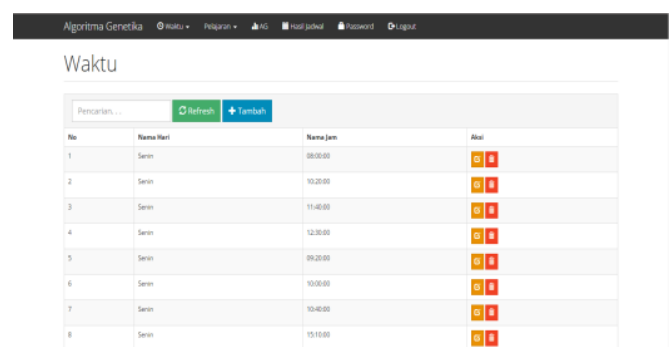

Gambar 4. Halaman Waktu

2. Halaman Data Hari

Halaman ini dipergunakan untuk menambah, mengubah dan menghapus data hari yang akan dipergunakan dalam proses penjadwalan mata pelajaran. Halaman ini akan menginputkan kode hari dan nama hari. Tampilan halaman data hari dapat dilihat pada gambar 6.4.

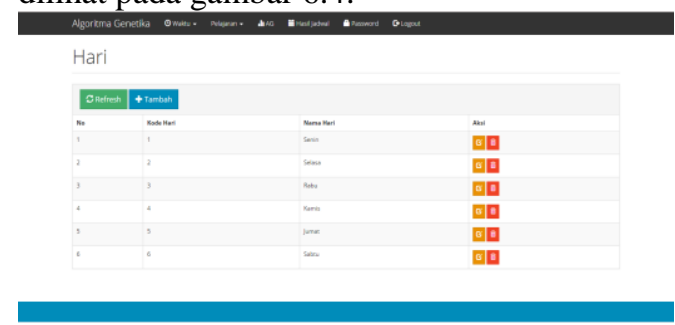

Gambar 5. Halaman Data Hari

3. Halaman Data Jam

Halaman ini dipergunakan untuk menambah, mengubah dan menghapus data jam yang akan dipergunakan dalam proses penjadwalan mata pelajaran. Tampilan halaman data hari dapat dilihat pada gambar 6.5.

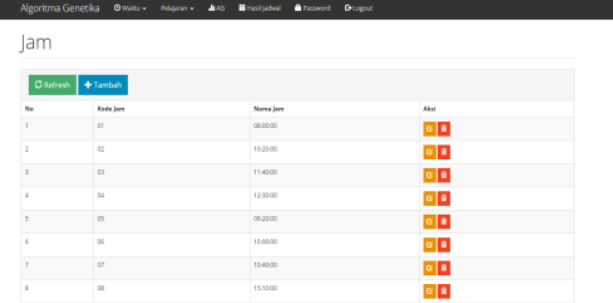

Gambar 6. Halaman Data Jam

4. Halaman Mata Pelajaran

Halaman mata pelajaran dipergunakan untuk melakukan proses menambah, mengubah serta menghapus mata pelajaran. Pada halaman mata pelajaran akan berisikan nama mata pelajaran dan jumlah jam mata pelajaran tersebut.
Tampilan halaman mata pelajaran dapat dilihat pada gambar 6.6.

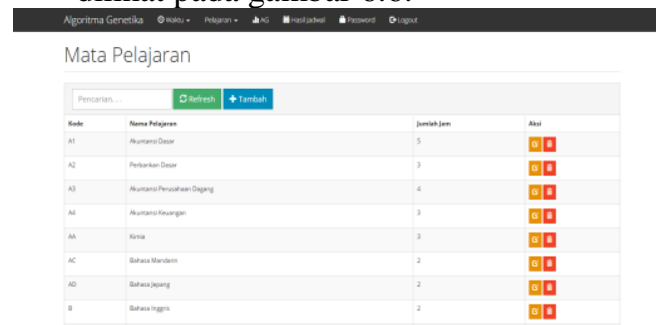

Gambar 7. Halaman Mata Pelajaran

\section{Halaman Data Guru}

Halaman data guru dipergunakan untuk menambah, mengubah dan menghapus data guru. Data pada halaman data guru berisikan kode guru, nama guru dan hari yang diinginkan untuk mengajar. Tampilan halaman data guru dapat dilihat pada gambar 6.7 .

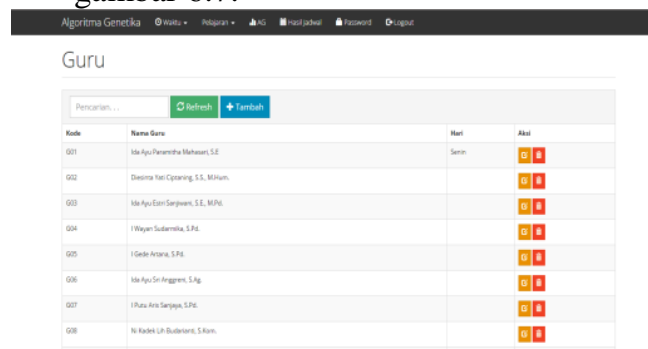

Gambar 8. Halaman Data Guru

6. Halaman Data Kelas

Halaman data kelas adalah halaman yang memiliki kegiatan untuk menambah, mengubah serta menghapus data kelas. Pada halaman ini berisikan kode kelas, jenjang, nama kelas dan jurusan. Halaman data kelas dapat dilihat pada gambar 6.8

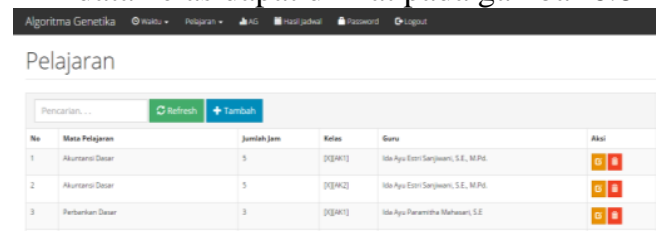

Gambar 9. Halaman Data Kelas

7. Halaman Data Pelajaran

Halaman data pelajaran merupakan halaman relasi antara data guru dengan kelas dan mata pelajaran. Pada halaman ini dapat dilakukan proses menambah, mengubah dan menghapus data pelajaran. Tampilan halaman data pelajaran dapat dilihat pada gambar 6.9 


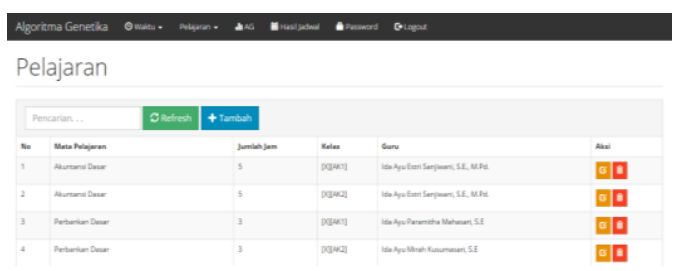

Gambar 10. Halaman Data Pelajaran

8. Halaman Penjadwalan dengan Algoritma Genetika

Halaman ini untuk menampilkan perhitungan algoritma genetika apabila user mencentang checkbox tampilkan proses algoritma dan menekan button generate jadwal. Tampilan ini dapat dilihat pada gambar 6.10.

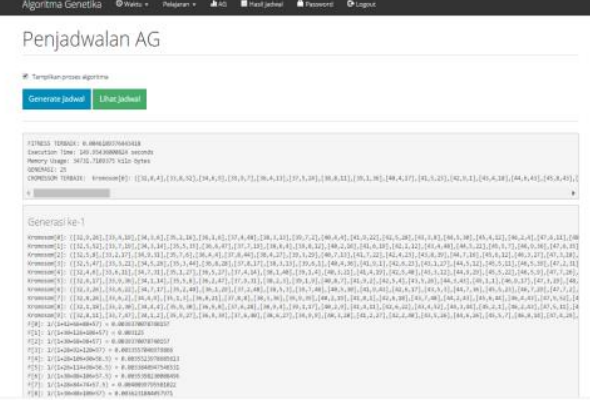

Gambar 11. Halaman Penjadwalan dengan Algoritma Genetika

9. Halaman Hasil Jadwal

Halaman ini akan memunculkan hasil penjadwalan dari sistem. Untuk melihat hasil jadwal user memilih kelas dan mengklik button refresh maka jadwal akan tampil dan untuk dapat mencetaknya user dapat menekan button cetak. Tampilan halaman hasil jadwal dan cetak dapat dilihat pada gambar 6.11 dan 6.12

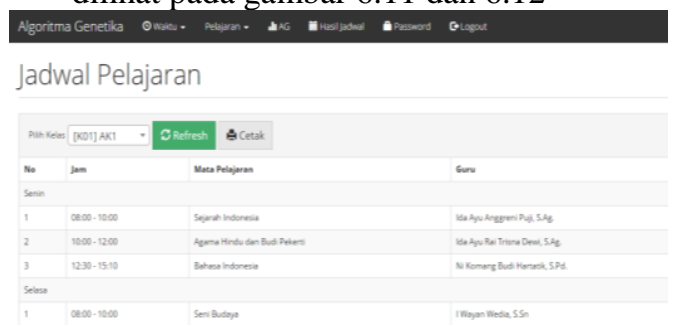

Gambar 12. Halaman Hasil Jadwal

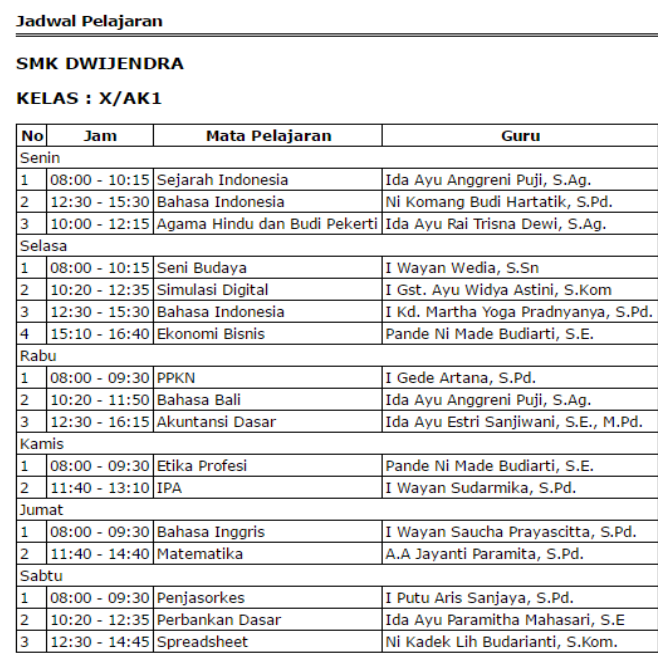

Gambar 13. Hasil Cetak Jadwal

\section{Pengujian Sistem}

Pengujian dilakukan setelah sistem penjadwalan dibangun. Pengujian pada sistem ini meliputi pengujian terhadap ukuran populasi dan pengujian terhadap ukuran generasi.

1. Pengujian Ukuran Populasi

Ukuran populasi yang dipergunakan dalam pengujian ini adalah 10 sampai dengan 150 dengan nilai $\mathrm{cr} 50 \%$. Hasil dari pengujian ukuran populasi dapat dilihat pada gambar 6.13 .

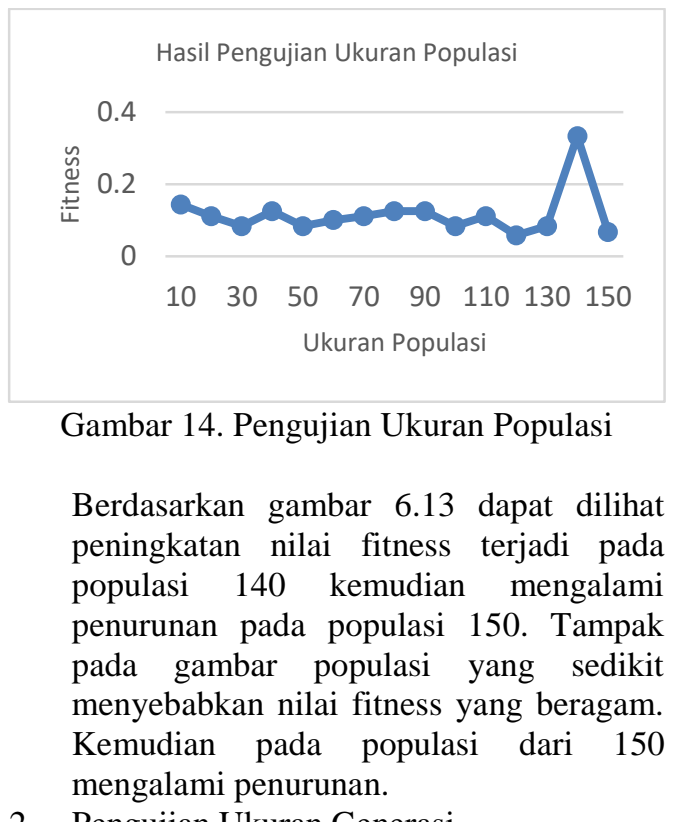

2. Pengujian Ukuran Generasi 
Pengujian ukuran generasi menggunakan data dari 10 hingga 150 dengan nilai $\mathrm{cr}$ 50\%. Pada ukuran generasi 60 dan 70 terpilih sebagai ukuran generasi yang menghasilkan nilai fitness teroptimal dan tidak mengalami perubahan dibandingkan pada ukuran populasi lainnya yang menghasilkan nilai yang beragam. Hasil pengujian ukuran generasi ini tampak pada gambar 6.14

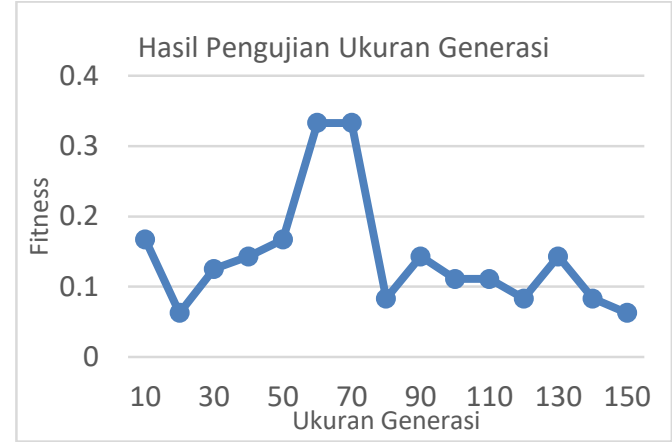

Gambar 15. Hasil Pengujan Ukuran Generasi

\section{SIMPULAN}

Penjadwalan mengajar dengan algoritma Genetika dengan studi kasus di SMK Dwijendra dapat dilakukan dengan menggunakan data matapelajaran dan guru dari SMK tersebut dan menghasilkan jadwal mengajar bagi guru di sekolah tersebut sehingga tidak terjadinya bentrokan jadwal.

Hasil pengujian yang dilakukan pada penelitian ini yaitu dengan pengujian pengukuran ukuran populasi dan ukuran ukuran generasi. Pada pengujian tersebut dilakukan dengan menggunakan ukurun populasi dan generasi sebanyak 150 dengan crossover rate (cr) 50\%. Hasil pengujian menunjukan bahwa pada populasi dan generasi sedikit menghasilkan nilai fitness yang beragam. Nilai fitness yang baik dihasilkan pada populasi dan generasi diatas 50 .

\section{DAFTAR PUSTAKA}

[1] Ayu, I. G., Saryanti, D., dkk. 2017. "Penerapan Metode Algoritma Genetika Untuk Penjadwalan Mengajar", 8(1), 53-60.

[2] Fachrudin Afandi, Mahendrawathi ER, S.T, M.Sc, Ph.D, Faizal Mahananto, S. K. 2009. "Penerapan algoritma genetika untuk masalah penjadwalan". Fakultas Teknologi Informasi, Institut Teknologi Sepuluh Nopember (ITS), 1(3), 1-7.

[3] Kadir, A. 2006. Dasar Pemrograman Web Dinamis Menggunakan PHP. Yogyakarta: ANDI.

[4] Maharsi, A. L. 2013. "Sistem penjadwalan mata pelajaran sekolah menggunakan algoritma genetika. Skripsi", 1-164.

[5] Puspaningrum, W. A., Djunaidy, A., dkk. 2013. "Penjadwalan Mata Kuliah Menggunakan Algoritma Genetika di Jurusan Sistem Informasi ITS". Jurnal Teknik Pomits, 2(1), 127-131. https://doi.org/10.12962/j23373539.v $2 \mathrm{i} 1.3234$.

[6] Suyanto 2005. Algoritma Genetika Dalam Matlab. Yogyakarta: Andi. 